\title{
Research on Content System of Economic Activity Analysis of Power Grid Enterprises Based on Full Professional Integration
}

\author{
Shanshan $\mathrm{Wu}^{1, \mathrm{a}^{*}}$, Lili Zhang ${ }^{2, \mathrm{~b}}$ and Liu Dian ${ }^{3, \mathrm{c}}$ \\ ${ }^{1}$ State Grid Energy Research Institute, Beijing, China \\ ${ }^{2}$ State Grid Energy Research Institute, Beijing, China \\ ${ }^{3}$ School of Environment \& Natural Resources, Renmin University of China, Beijing, China \\ awushanshan@sgeri.sgcc.com.cn, bzhanglili@sgeri.sgcc.com.cn, ${ }^{\mathrm{c}}$ dianliu@ruc.edu.cn
}

Keywords: Power grid enterprise; Economic activity; Management efficiency; Macro economy; Electricity market; Production of enterprises

\begin{abstract}
The economic activity analysis of power grid enterprises is not only one of the bases for the government departments to supervise but also the necessary means for power grid enterprises to improve their own operating efficiency. At present, the business environment of power grid enterprises has undergone great changes. It is necessary to re-sort the contents of the analysis and set up a scientific and reasonable analytical content system. The theory of enterprise production and management is the main theoretical support of this study. At the same time, we draw lessons from two economic activities analysis cases of thermal power enterprises and railway enterprises, and summarize the ideas, contents and specific indicators of economic activities of industrial enterprises. Therefore, it is necessary to clarify the connotation of economic activities of power grid enterprises in the new situation, put forward five major principles to be followed, and give the analysis ideas. Based on the logical relations and specific indexes of eight modules such as macroeconomic environment, power market environment, production and marketing, financial management, power grid development, power grid operation, new energy and human performance, the paper analyzes the economic activities of power grid enterprises based on full professional integration system.
\end{abstract}

\section{Introduction}

At present, China has more than ten Power Grid Corp, all of which are state-owned, including two large Power Grid Corp and more than a dozen local Power Grid Corp, undertaking China's power transmission and distribution network construction and power supply, sales and other business. The analysis of the economic activities of the power grid enterprises is not only one of the bases for the government departments to supervise the power grid companies, but also the necessary means for the power grid enterprises to improve their own operating efficiency. Economic activity analysis is an important economic management activity that provides a scientific basis for enterprise decision-making. It is an important way to improve the management level of an enterprise. Its main purpose is to solve the problems in production and operation. The power grid is an important foundation that relates to the national energy security and the lifeline of the national economy. It is also an important carrier for optimizing and adjusting the industrial structure and promoting the transformation of the mode of economic growth. The power grid enterprise has a great mission. The state-owned nature of power grid enterprises determines that their operational benefits include not only the preservation and appreciation of state-owned assets, but also the public welfare functions of ensuring energy security, practicing energy strategies and adjusting economic development. In addition, the technology-intensive, capital-intensive industries and the single product cannot be stored in the industry determine the content and focus of the economic activities of power grid enterprises will also be different from other companies.

With the Chinese economy entering a "new normal", the situation of production and operation of China's power grid enterprises is undergoing major adjustments. First, the major propositions and new policies adopted by the state in guiding innovation, regional coordinated development of urban and rural areas, the strategy of the Belt and the Road, the operating environment for power grid 
enterprises and the target requirements are more diverse. The contents of economic activity analysis must increase the depth and breadth of the analysis and prediction of the external environment. Second, the reform of the state economic system has entered a crucial stage. Coupled with the continuous promotion of state-owned enterprise reform and power market reform, the operation mode of the Company is profound Change, requiring economic activity analysis to find problems and find solutions based on the perspective of full professional analysis. Third, the decision-makers of power grid enterprises attach great importance to the analysis of economic activities put forward higher requirements, analysis of the timeliness, accuracy and closed-loop Features will be further highlighted. Therefore, on the basis of current work, it is necessary to conduct a research on the system of analysis of economic activities based on full professional integration for power grid enterprises.

\section{Theoretical Basis}

At present, there are few researches on the analysis of the economic activities of enterprises. This dissertation starts with the theoretical basis of supporting research and combines with the development of economic activity analysis to provide reference and reference for this study.

Business management is an important foundation for economic activity analysis. Its theoretical basis mainly includes the theory of enterprise production and management. French management scientist Fayol proposed five major elements of management in 1961: planning, organizing, coordinating, directing, controlling and so on. Ansoff established the theoretical system of modern strategic management after the 1980s. Michael Porter took the strategic management to its peak. With the rapid development of globalization and informatization, Peter Senge put forward the importance of establishing a learning organization. Since then, the external environment such as politics, economy and society has become an important foundation and key link in the development of enterprise production and operation. In order to ensure the smooth operation of business activities, enterprises need to collect timely information on external conditions as the external constraints and boundary conditions for their production and operation.

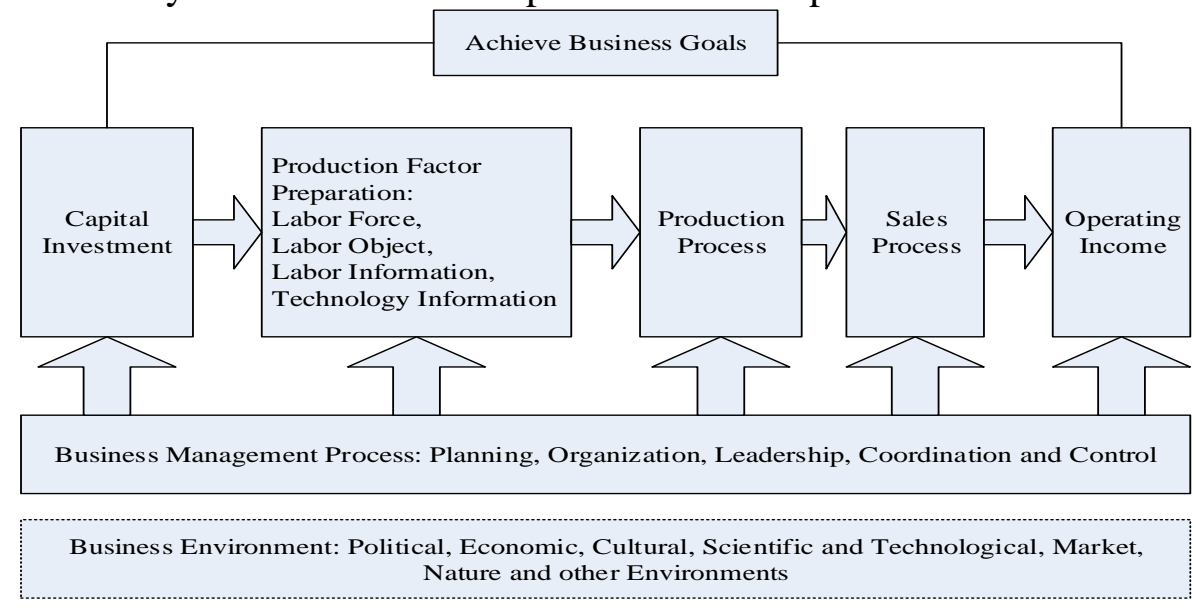

Figure 1. Production process diagram

The analysis of corporate economic activity originated in corporate financial analysis, with Thomas Wood Lock publishing the first book of financial analysis in 1900. After that, Alexander Wall, Dunning and Novell gradually enriched and enriched the content, and the methods of analysis were more scientific and perfected. The internal analysis of the enterprise gradually completed the analysis from financial analysis Conversion to economic analysis. The analysis of economic activity of Chinese enterprises started relatively late, and it was only in its embryonic form in the 1950s. After nearly 50 years of accumulation of practical experience, the analysis of economic activities has progressed in depth and has become increasingly rich in content. From the initial balance sheet, Financial analysis, to economic analysis based on a set of accounting data, including all aspects of economic activities; from the general financial analysis to the technical and economic analysis of 
the production characteristics of various industries; from the analysis and development of enterprises as the object, further development To the internal accounting units of the analysis and expanded to the economic analysis of the sector; from a simple comparison of the actual enterprise and the plan or the previous period, the development of comparison between enterprises, compared with the industry; from a single after-the-fact analysis of the development of things Analysis and prediction in advance, decision analysis.

In summary, this paper considers that the content of economic activities analysis of power grid enterprises includes at least the following contents: preparation of human, financial and material resources, indicators involved in the production process, sales, revenue and various indicators during the next round of investment, Business environment related content.

\section{Practical Experience}

In order to focus more effectively support the company's economic activity analysis, this article mainly selected industrial enterprises for analysis.

\section{A Thermoelectric Company}

Analysis of Ideas. The thermoelectric company A uses the whole process of analysis of theoretical ideas to establish the framework of pre-forecasting, event control and post-event analysis, as shown in the following figure. Using DuPont analysis model principle, two main lines of financial analysis, production and technical analysis are set up Level analysis of economic activity index system; combined with the production and management of enterprises, designed a set of economic activities to adapt to their own characteristics of economic analysis system.

Through the analysis of economic activities, summing up the past experience, find the weak links in the production and operation of enterprises, indicating the direction of improvement of enterprises.

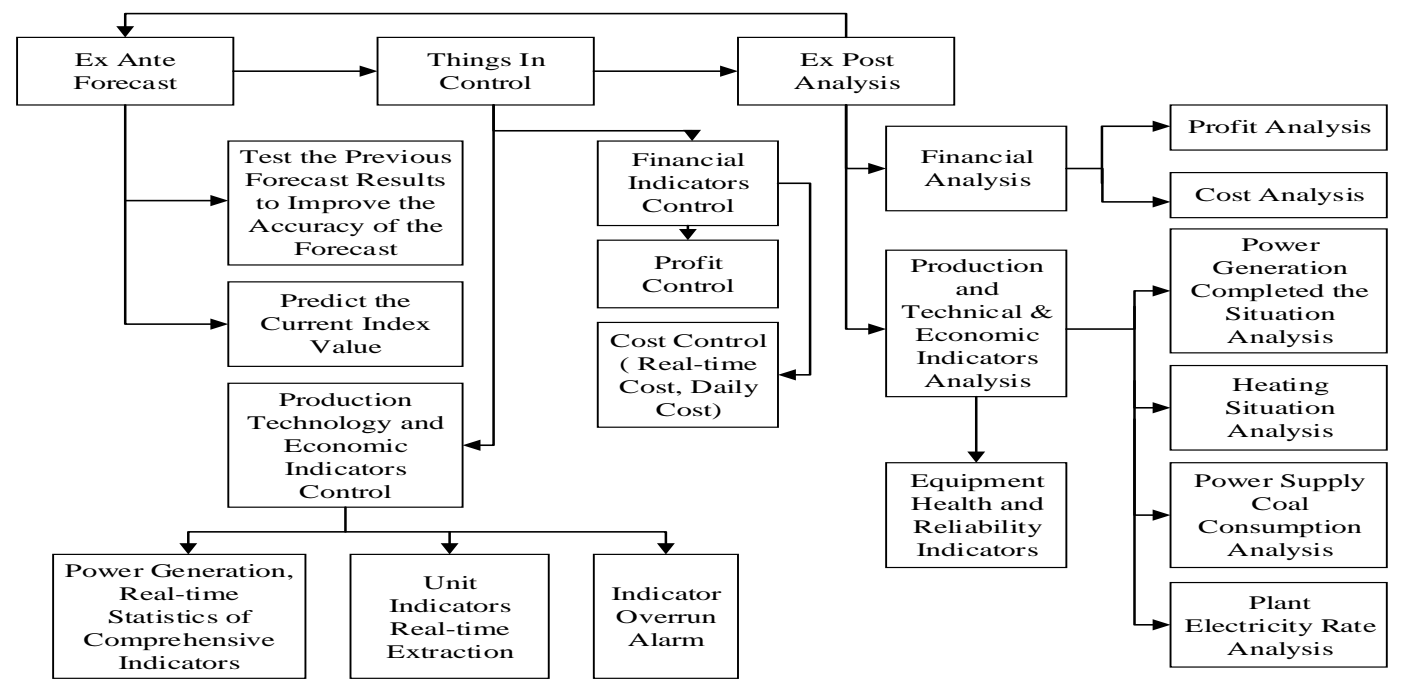

Figure 2. Based on the whole process of economic analysis of the thermoelectric industry framework

Analyze the Content. (1) clear the whole process of analysis of the various stages of focus: mainly for the prediction in advance, things in control and post-mortem analysis. (2) Financial Analysis Taking profit as the starting point for analysis, we decompose a level (power income, variable costs, etc.) and secondary indicators (electricity consumption on the grid, fuel costs, etc.) Cost, etc.), using gray model, sensitivity analysis, factor analysis and other methods to carry out correlation analysis. (3) Production and technical analysis Focusing on coal consumption, plant electricity consumption, equipment operation status and reliability related indicators, a comparative analysis method is used to evaluate the changes of the indicators.

Analysis of Indicators. The structure of production and technical and economic indicators in the economic activity of hot spot enterprise $\mathrm{A}$ is shown in the following table. 
Table 1 Production and technical and economic indicators structure

\begin{tabular}{|c|c|c|}
\hline $\begin{array}{l}\text { First-level } \\
\text { indicators }\end{array}$ & $\begin{array}{l}\text { Second-level } \\
\text { indicators }\end{array}$ & Third-level indicators \\
\hline $\begin{array}{l}\text { Power supply } \\
\quad \text { coal } \\
\text { consumption }\end{array}$ & $\begin{array}{l}\text { Boiler efficiency } \\
\text { Turbine } \\
\text { efficiency }\end{array}$ & $\begin{array}{c}\text { Oxygen, fly ash, exhaust gas temperature } \\
\text { Steam pressure, steam temperature, water temperature, } \\
\text { circulating water temperature }\end{array}$ \\
\hline \multirow{5}{*}{$\begin{array}{l}\text { Plant electricity } \\
\text { rate }\end{array}$} & $\begin{array}{l}\text { Feed pump } \\
\text { electricity rate }\end{array}$ & Feed pump electricity consumption \\
\hline & $\begin{array}{l}\text { Powder } \\
\text { electricity rate }\end{array}$ & Milling power consumption \\
\hline & Fan power rate & Fan power consumption \\
\hline & $\begin{array}{l}\text { Circulation pump } \\
\text { electricity rate }\end{array}$ & -- \\
\hline & $\begin{array}{l}\text { Other production } \\
\text { electricity rate }\end{array}$ & -- \\
\hline \multirow[t]{2}{*}{$\begin{array}{l}\text { Equipment } \\
\text { health status }\end{array}$} & $\begin{array}{l}\text { Host health } \\
\text { status }\end{array}$ & $\begin{array}{l}\text { Equipment utilization hours, hours of operation, planned } \\
\text { outage hours, unplanned outage hours, forced outage hours, } \\
\text { outage forces equivalent outage hours, equivalent usable } \\
\text { factors, equivalent forced outage rates }\end{array}$ \\
\hline & $\begin{array}{l}\text { Auxiliary } \\
\text { operation }\end{array}$ & $\begin{array}{l}\text { MTBF, non-stop times, planned outage factor, unplanned } \\
\text { outage factor, available factor, operating factor }\end{array}$ \\
\hline
\end{tabular}

\section{A Railway Company}

Analysis Ideas. Based on the whole process analysis theory, the railway enterprise B proceeded from the three aspects of before, during and after the event. Based on the prediction, control and analysis, the railway enterprise B refined a whole framework of economic activities throughout the whole process and clearly reflected the financial status of the enterprise, Intuitive display of financial problems, accurately identify the business drivers behind the problem.

Analyze the Content. (1) The profit target is divided into income and cost indicators. (2) Establishing indicators for the completion of production tasks, management and labor index, material and management indicators and other indicators for analysis. (3) Profit and loss analysis method, analysis of profit and loss reasons.

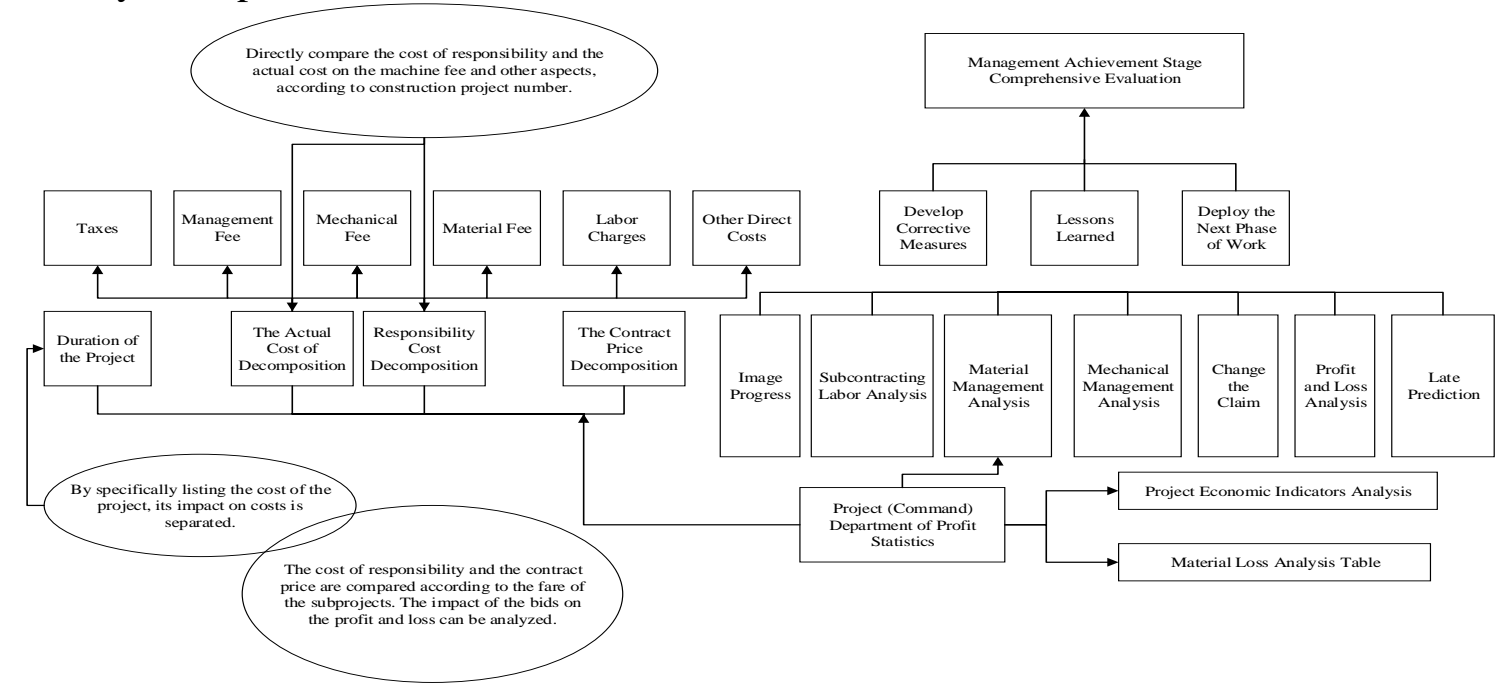

Figure 3. Based on the whole process of economic activity of railway enterprises analysis framework 
Analysis of Indicators. The analysis of economic activities of railway enterprises mainly includes profit, cost and income. The costs are divided into material costs, mechanical costs, labor costs, management fees, taxes, other expenses and the reasons for the costs include not timely settlement, Reasons for changes in revenue Design changes, policy adjustments, revenue recognition time differences.

\section{Content System Construction}

\section{Connotation}

Combining theoretical foundation and practical experience, this paper puts forward the connotation of economic activities analysis of power grid enterprises: centering on the economic efficiency and operational efficiency of enterprises, integrating the content analysis framework, screening the key business indicators and systematically reflecting the business development of the company; Advantage and accurate positioning of the company's operation and management of the key issues and deep-seated reasons, put forward feasible measures suggestions, closed-loop management to strengthen implementation, and promote optimization and improvement of corporate governance.

\section{Analysis Ideas}

In view of the analysis of the economic activities of power grid enterprises, this paper puts forward the principles that economic activities of companies need to follow:

Comprehensiveness: The function of economic activity analysis of the Company is to fully and accurately reflect the specific conditions and existing problems in the production and operation of the Company, and provide support for clarifying the key work of the Company in the next step. Therefore, analyzing the comprehensiveness of the content is the first principle of constructing the index system.

Focusing: The two main lines of "efficiency" and "efficiency" are highlighted. According to the analysis needs, relevant indicators reflecting the efficiency and effectiveness should be appropriately added to the core index system.

Availability: The analysis of economic activity of the Company aims at supporting business decision-making. The analysis of indicators should be quantitatively analyzed as much as possible, and the data frequency should meet the requirements of quarterly and even monthly analysis. Therefore, the accuracy and stability of data sources Sex has high requirements.

Problem-orientedness: The analysis of economic activity of a company is an activity aimed at discovering problems, analyzing problems and developing tendency of judging problems. Therefore, the design of content system should fully consider the need of finding problems, and the content system should be designed according to problem orientation .

Versatility: The analysis of economic activities runs through the headquarters of the Company, all units and units at all levels and therefore requires high universality of the indicators. The selection of indicators should ensure that the concept of the indicators of different regions and different time in the company system is clear and consistent in caliber so as to meet the comparison and correlation analysis among different regions, units, different periods and different indicators across the Company. 


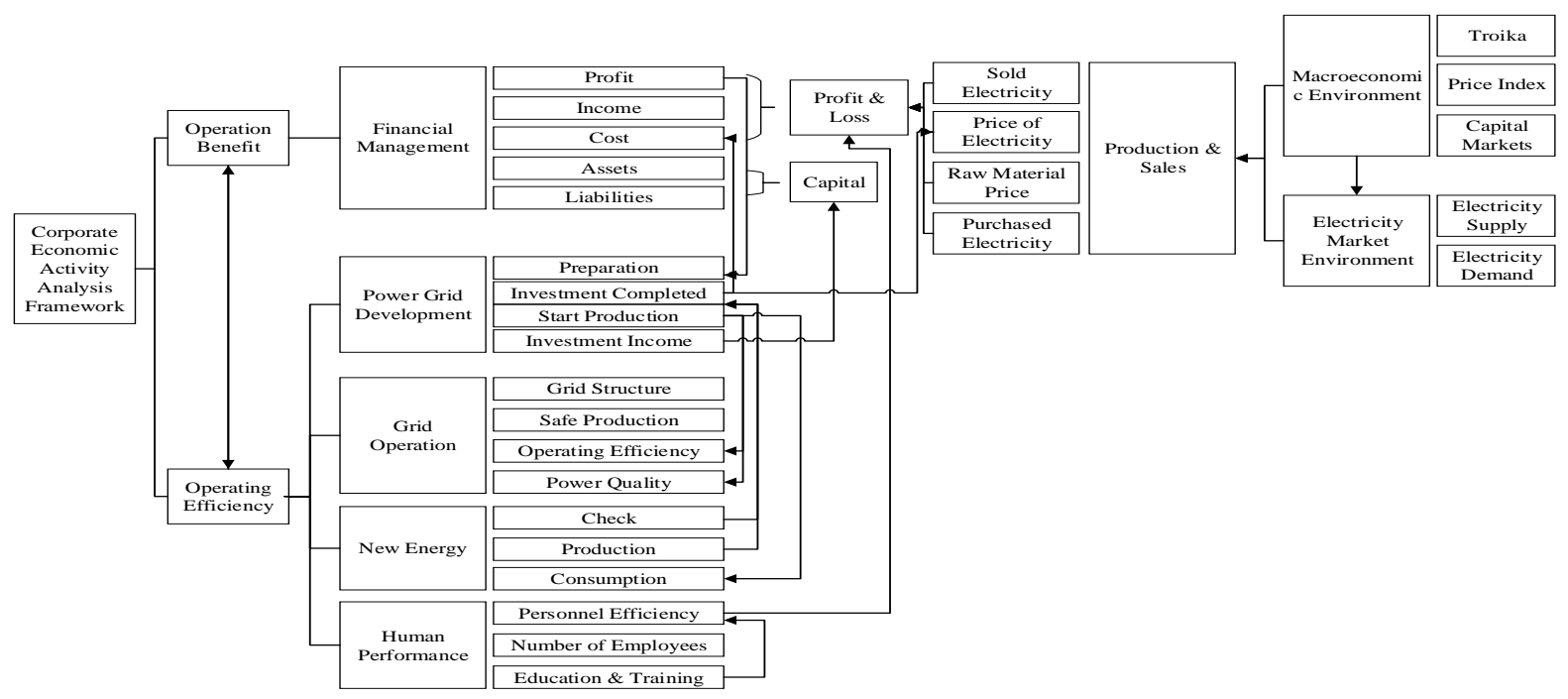

Figure 4. Grid business analysis of economic activities

\section{Analysis of Content}

According to the analysis of economic activity, the analysis of economic activities of power grid enterprises includes eight modules of macroeconomic environment, power market environment, production and marketing, financial management, power grid development, grid operation, new energy and human performance.

The operation of power grid enterprises is closely related to the macroeconomic environment. The macroeconomic conditions and other economic and non-economic factors directly or indirectly affect the power industry and affect the production and operation of power grid enterprises. As a kind of advanced productive forces and basic industries, the power industry in which power grid enterprises are located has a very close relationship with economic and social development. On the one hand, power demand is inevitably affected by many factors, such as economic growth and economic structure. On the other hand, with the economic and social development in our country, technological progress will promote a cleaner and more efficient development of the power industry. Therefore, in the analysis of the economic activities of power grid enterprises, the macroscopic economy needs to be analyzed as an important module as a macro environment for the development of enterprises.

Power grid enterprises in the construction and operation of the power grid as the core business in the power industry in the pillar industries of the national economy, its economic activity analysis will inevitably be affected by the power market environment, specifically, the power market environment, including the power supply environment and power demand environment, Of which the supply of electricity mainly affects the purchase cost of power grid enterprises. The demand of power mainly affects the sales of power grid enterprises. Therefore, the analysis of economic activities needs to be conducted from the perspective of power supply, power demand and power balance.

Production marketing is an important factor affecting the operating efficiency of power grid enterprises. Power marketing is in the ever-changing power market, focusing on the needs of power customers, enabling power users to use safe, reliable, qualified and economical power commodities through the power supply and demand relationship, and being thoughtful and satisfying. Meanwhile, the power grid Businesses can gain sustainable benefits by increasing their sales of electricity, enhancing their brands, and more. Therefore, production marketing is an important factor that affects the operating efficiency of power grid enterprises. The main considerations of the module include the purchase and sale of electricity, industry expansion, market share and line loss rate.

Analysis of business efficiency is the main line of economic activity analysis. It is necessary to analyze and master the relevant factors that affect the operating efficiency of enterprises, find out the weak links or crux of the problem, and then determine the effective and effective ways to improve business efficiency. Benefit analysis includes revenue, cost, profit, assets, and other 
financial indicators. According to the grid enterprise organizational structure and business operations, business efficiency analysis using the total score approach, respectively, the power grid business in various sections of the various business efficiency indicators.

Grid development is a link between operating efficiency and operating efficiency of power grid enterprises. However, operating efficiency and operating efficiency are the two main lines of economic activity analysis of power grid enterprises. Therefore, the analysis of grid development needs to be carried out as a module in the analysis of economic activities of power grid enterprises. Grid development as part of operational efficiency, in addition to affecting the operation of power grids and new energy consumption, investment in power grids also affect the assets and liabilities in the financial management through capital formation. According to the process of power grid construction, the main contents of power grid development module analysis include power grid planning, preliminary work, power grid investment, start-up and commissioning, and information construction.

Grid operation is not only related to operational efficiency, but its safe and reliable operation also affects the operating efficiency and social safety of power grid enterprises. The safety and reliability of grid operation are closely related to the vital interests of each individual. When there are security problems in the grid, it will not only affect users' normal electricity use, but also cause the danger of electricity consumption and damage the interests of society People's life. In addition, the grid operation accidents will bring economic losses to the power grid enterprises, so that the power grid corporate image suffered. The grid operation analysis mainly includes the number of grid accidents, casualties, power supply reliability and other indicators.

Clean and efficient power industry is the direction of development, and new energy consumption is the embodiment of grid efficiency. Operating efficiency As one of the main lines of economic activity analysis, new energy development needs to be included. According to the needs of sustainable economic and social development, it is urgent to establish an energy structure based on clean and renewable energy instead of the fossil energy-based energy structure with serious pollution and limited resources. New energy consumption can not be separated from the development of power grid construction, and with the new energy power generation technology, new energy power generation costs also contributed to the decline in power grid construction. Therefore, new energy sources as a module of the economic activities of power grid enterprises. Analysis of new energy development module includes new energy grid capacity, new energy power generation, new energy online, utilization hours and so on.

Human performance management helps enterprises to achieve the strategic development goals, and is the key guarantee for the grid enterprises to gain their core competitiveness. Human resources performance management level affects all aspects of power grid business operations, but also an important basis for all professional integration. Human performance module analysis includes the number of workers, labor productivity, education and training.

\section{References}

[1] M. Zeng: Power Enterprise Program Management and Its Technical Support System (China Electric Power Press, China 2001). (In Chinese)

[2] S.P. Yang, Y.L. Zhao, S.J. Fu, J. Zhou and M. Zeng: Electric Power Technologic Economics, Vol. 18 (2006) No.5, p.41. (In Chinese)

[3] M. Han, and Z.Q. Tian: Times Finance, Vol. 33 (2011) No.11, p.236. (In Chinese)

[4] Z.W. Wang and Y.Q. Xin: Qinghai Electric Power, Vol. 42 (2012) No.12, p.32. (In Chinese)

[5] Y. Li and Y.H. Wang: Journal of North China Electric Power University (Social Sciences), Vol. 4 (2008) No.2, p.8. (In Chinese)

[6] Y. Liu: Shaanxi Electric Power, Vol. 36 (2008) No.7, p.70. (In Chinese)

[7] J.Q. Sun: Shandong Electric Power, Vol. 42 (2015) No.1, p.78. (In Chinese)

[8] W.S. Tong: Hubei Electric Power News, Vol. 26 (2012) No.2, p.22. (In Chinese)

[9] N.H. Xue, M.L. Lv and T. Li: Central China Electric Power, Vol. 11 (1998) No.3, p.24. (In Chinese) 